\title{
EFFECT OF LIME (Citrus aurantifolia) JUICE AS SOURCE OF VITAMIN C ON PERFORMANCE AND SOME BLOOD PARAMETERS IN PELUNG CHICKENS (Gallus gallus domesticus)
}

\author{
Lilik KRISMIYANTO ${ }^{\star \otimes}$, Hanny Indrat WAHYUNI and dan Nyoman SUTHAMA \\ Department of Animal Science, Faculty of Animal and Agricultural Science Universitas Diponegoro, Semarang City 50275, Indonesia
}

Email: lilikkrismiyanto@lecturer.undip.ac.id; (1) ORCiD: 0000-0001-5634-6965

supporting Information

\begin{abstract}
Pelung chicken (Gallus gallus domesticus) is a typical Indonesian local breed originating from West Java. Pelung chicken breeding, especially male bird, was initially used as a hobby livestock because they have tunable voice. This study aimed to evaluate the effect of feeding lime (Citrus aurantifolia) juice as a source of vitamin $\mathrm{C}$ on blood parameter and performance of male pelung chickens. The experimental birds were 64 male pelung chicken aged 12 weeks, divided into 4 weight groups namely group 1: 740 - $910 \mathrm{~g}$, group 2: $910-1,080 \mathrm{~g}$, group 3: 1,080 - 1,250 g, and group 4: 1,250 - 1,420. The treatments applied were T0: formulated diet; FD, T1: FD+ lime juice 1\%, T2: FD + lime juice 2\%, and T3: FD + lime juice $3 \%$. The present experiment was assigned in body weight-based randomized block design. Measured parameters were heterophile, lymphocyte, heterophile-lymphocyte ratio $(\mathrm{H} / \mathrm{L})$, total plasma protein, the relative weight of lymphoid organs (spleen and bursa of fabricius) and performance (feed intake, daily body weight gain and feed conversion ratio) of birds. The results showed that the feeding diet added with $1-3 \%$ lime juice significant on heterophile, $\mathrm{H} / \mathrm{L}$ ratio, the relative weight of spleen, total plasma protein, daily body weight gain and feed conversion ratio, but not significant on lymphocyte, the relative weight of bursa of fabricius and feed intake. Male pelung chicken fed diet added with $3 \%$ lime juice (T3) indicates better blood parameter stability (H/L ratio and lymphoid organs), total plasma protein and performance.
\end{abstract}

Keywords: Blood parameter, Lime, Pelung chicken, Performance, Vitamin C.

\section{INTRODUCTION}

The are many kinds of local chickens in Indonesia throughout the country, such as Kedu, Sentul, Nunukan, Pelung, Sumatra, Bekisar chickens and others. The local chicken population in the last 10 years has increased significantly between 249,963,499 to 310,959,951 birds (Directorate General of Livestock and Animal Health, 2020). Pelung chicken are local Indonesian poultry originated from Cianjur, West Java, which has existed since 1850 (Asmara et al., 2019). This type of chicken is well known as a fancy bird and the body weight of the ready-to-cut at 12 weeks old can achieve between $700-800 \mathrm{~g}$ (Hidayat and Asmarasari, 2015). Indonesian local poultry, including pelung chickens, are generally known to be adaptive well to the tropical environment (Sumantri et al., 2020). However, efforts to maintain body resistance in order to be more adaptive to the fluctuating tropical environment need providing natural additives are important. Body resistance is generally related to the ability of natural additives work as a source of antioxidants (Zhou et al., 2019; Righi et al., 2021).

The provision feeding diet with additives containing antioxidant and anti-stress substances are very relevant with the aim to increase immune-related blood parameter (Surai et al., 2019; Marimuthu et al., 2020). A suitable natural additive that is locally available as an antioxidant and anti-stress is lime juice which is rich in vitamin C (Elwan et al., 2019; Ali, 2020). Shrestha et al. (2012) reported that the content of vitamin $C$ in lime juice is equal to $118.2-140.8 \mathrm{mg}$ per $100 \mathrm{~g}$. Vitamin $C$ in particular, has been proven to be beneficial in over-coming cold and heat stress in tropical region (Kusnadi, 2009). Vitamin C supplementation is also reported to be effective in increasing heat resistance during maintenance at high temperatures (Sahin et al., 2003) and very efficient in regulating the activity of amylase enzyme and uric acid metabolisms in broilers (Imik et al., 2013). Amylase activity and uric acid metabolisms are both in related to the ability of glucose and blood protein regulations due to heat stress (Belhadj Slimen et al., 2016). Ferreira et al. (2015) showed that vitamin $\mathrm{C}$ can prevent the effect of heat on broilers reared at $39{ }^{\circ} \mathrm{C}$ which is characterized by the difference in body weight gain with the area of meat fiber specifically increase as compared to control.

Although chickens capable in producing their own endogenous vitamin C, but is not enough to overcome stress when reared in the tropical region (Abidin and Khatoon, 2013). Therefore, they require exogenous vitamin $C$ supplementation. The use of lime juice as a source of vitamin $C$ is very relevant for raising chickens in the tropical environments that possible for the adaptation process. Dietary addition of lime juice is expected to increase blood parameter of Pelung chickens, since vitamin $\mathrm{C}$ functions as an antioxidant. Although, free radical was not observed in the 
present study, vitamin $\mathbf{C}$ is known to be able. Vitamin $\mathbf{C}$ is able to donate electrons and hydrogen to the free radicals; consequently free radicals become relatively stable. Criteria for blood parameter in present study included ratio of heterophile-lymphocytes $(\mathrm{H} / \mathrm{L})$ and blood plasma protein. $\mathrm{H} / \mathrm{L}$ ratio is the main stress indicator in poultry, because the higher the ratio number, the severe stress level is experienced, and vice versa (Kusnadi, 2009). Plasma protein is a secondary indicator of blood parameter besides the $\mathrm{H} / \mathrm{L}$ ratio, because it is an indication of an adequacy supply of amino acids for antibody formation. The general phenomenon is that the higher plasma protein, the better blood parameter of chickens that support productivity.

\section{MATERIALS AND METHODS}

\section{Experimental animal and diet}

The experiment used 12-week old of 64 male birds obtained from in situ maintenance (native habitat) in Cianjur, West Java, divided into 4 groups based on body weight (group 1: 740-910 g, group 2: 910-1,080 g, group 3: 1,0801,250 g, and group 4: 1,250-1,420 g) and reared for 6 weeks. Basal diet composed of rice bran, yellow corn, white bran, soybean meal, meat bone meal, and mix mineral which are prepared with a crude protein content of $14.57 \%$ and metabolizable energy (ME) of 2,892.03 kcal/ $\mathrm{kg}$ (Table 1). Lime juice according to treatment level at 1, 2 and $3 \%$ were mixed with approximately $\mathbf{2 0} \mathrm{g}$ of diet and given in the morning, to ensure all lime juice can be complete consumed, and followed by diet without lime juice to fulfill daily requirement. Experimental diets were provided from 13 week to 18 week old after condition period for one week (12-13 week).

Table 1 - Compositions and nutrient content for formulated diet.

\begin{tabular}{|c|c|}
\hline Ingredients & Compositions (\%) \\
\hline Rice bran & 20.00 \\
\hline Yellow corn & 55.00 \\
\hline Wheat bran & 10.00 \\
\hline Soybean meal & 6.00 \\
\hline Meat bone meal & 4.00 \\
\hline Mineral and vitamin mix ${ }^{3}$ & 5.00 \\
\hline Total & 100.00 \\
\hline Metabolizable energy (kcal/kg)² & $2,892.03$ \\
\hline Crude Protein ${ }^{1}$ & 14.57 \\
\hline Crude Fiber ${ }^{1}$ & 7.37 \\
\hline Ether extract ${ }^{1}$ & 6.57 \\
\hline Calcium ${ }^{1}$ & 0.81 \\
\hline Total phosphor & 0.55 \\
\hline
\end{tabular}

\section{Experimental Parameters}

Observed parameters were heterophile, lymphocytes, heterophile-lymphocytes ratio, plasma protein and lymphoid organs (spleen and bursa of fabricius) measured at fifth the last week of experimental rearing period. Blood samples were taken through the brachial vein with $3 \mathrm{~mL}$ syringe. Blood was inserted into tube containing anticoagulant as was used sample for heterophile-lymphocyte test and total plasma protein based on Enzyme-Linked Immunosorbent Assay (ELISA) method. Chickens were further decapitated and dissected to obtain lymphoid organs (spleen and bursa of fabricius) to measure relative weight by dividing with final body weight and multiplied by $100 \%$.

\section{Experimental design and statistical analysis}

The study was arranged in a randomized block design (RBD) based on body weight and as follows:

$\mathrm{K} 1$ = body weight range $740-910 \mathrm{~g}$ with average $835.51 \pm 49.48 \mathrm{~g}$

$\mathrm{K} 2$ = body weight range $>910-1,080 \mathrm{~g}$ with average $985.69 \pm 42.04 \mathrm{~g}$

$\mathrm{K} 3=$ body weight range $>1,080-1,250 \mathrm{~g}$ with average $1,160.63 \pm 55.69 \mathrm{~g}$

$\mathrm{K} 4=$ body weight range $>1,250-1,420 \mathrm{~g}$ with average $1,369.06 \pm 65.97 \mathrm{~g}$

The study was designed in 4 treatments and 4 groups as replications ( 4 birds each). The treatment applied:

TO $=$ formulated diet

$\mathrm{T} 1=$ formulated diet + lime juice $1 \%$

T2 = formulated diet + lime juice $2 \%$

T3 = formulated diet + lime juice 3\%

Data subjected to analysis of variance to determine the effect of treatment. If the treatment indicated significant effect, it then followed by Duncan's test at $5 \%$ probability (Gomez and Gomez, 1984). 


\section{Ethical Approval}

The in vivo study was supervised by the Animal Ethics Committee of the Faculty of Animal and Agricultural Sciences,

Universitas Diponegoro and managed in accordance with the recommendations in the basic animal husbandry and health protocols referred to in Legislation of the Republic of Indonesia No. 18, 2009.

\section{RESULTS AND DISCUSSION}

\section{Blood parameter and immune organ}

Dietary addition of lime juice indicated significant effect on heterophile, heterophile-lymphocyte $(\mathrm{H} / \mathrm{L})$ ratio, total plasma protein, and spleen relative weight $(p<0.05)$, but it did not affect lymphocytes and the weight of the bursa of fabricius (Table 2). Heterophile and $\mathrm{H} / \mathrm{L}$ ratio in the treatment with the addition of $3 \%$ lime juice (T3) was the same as does the feeding of $2 \%$ lime juice (T2), but lower than the control/without lime juice (T0) and $1 \%$ lime juice treatment (T1). The total plasma protein due to with the feeding effect of $2 \%$ (T2) and $3 \%$ (T3) lime juice was higher than that in T0 and T1.

\section{Growth performance}

The dietary inclusion with lime juice had a significant effect $(p<0.05)$ on daily body weight gain (DBWG) and feed conversion ratio (FCR), but it did not affect feed intake of diet had the same value. The addition of lime juice at 1\% (T1), 2\% (T2), and 3\% (T3) significantly $(p<0.05)$ increased on DBWG and higher compared to formulated diet (T0). Feed conversion ratio with lime juice addition at $2 \%$ (T2) and 3\% (T3) were higher than that of T0, but between that of T2 and T3 treatments were not different from $\mathrm{T} 1$.

\section{Table 2 - Feeding lime juice on blood parameters and immune organs in male pelung chicken.}

\begin{tabular}{|c|c|c|c|c|c|c|}
\hline Parameter & TO & T1 & T2 & T3 & SE & P-value \\
\hline Heterophile (\%) & $70.05^{a}$ & $71.20^{a}$ & $40.62^{b}$ & $40.05^{b}$ & 8.12 & $0.035 *$ \\
\hline Lymphocyte (\%) & 60.12 & 62.00 & 50.12 & 60.10 & 1.26 & $0.200^{\mathrm{ns}}$ \\
\hline $\mathrm{H} / \mathrm{L}$ ratio & $1.16^{a}$ & $1.15^{a}$ & $0.81^{\mathrm{ab}}$ & $0.66^{b}$ & 0.24 & $0.050 *$ \\
\hline Total plasma protein $(\mathrm{g} / \mathrm{dl})$ & $4.25^{b}$ & $4.28^{b}$ & $4.35^{a}$ & $4.41^{\mathrm{a}}$ & 1.14 & $0.028 *$ \\
\hline Relative weight of spleen (\%) & $0.35^{a}$ & $0.32^{\mathrm{a}}$ & $0.28^{b}$ & $0.26^{b}$ & 0.44 & $0.047 *$ \\
\hline Relative weight of bursa of fabricius (\%) & 0.12 & 0.10 & 0.08 & 0.09 & 0.06 & $0.080 \mathrm{~ns}$ \\
\hline
\end{tabular}

\section{Table 3 - Feeding lime juice on growth performance of male pelung chicken.}

\begin{tabular}{|c|c|c|c|c|c|c|}
\hline Parameter & TO & T1 & T2 & T3 & SE & P-value \\
\hline Feed Intake (g/bird/day) & 107.99 & 114.08 & 109.03 & 111.27 & 1.35 & $0.250^{\mathrm{ns}}$ \\
\hline DBWG (g/bird/day) & $12.85^{b}$ & $15.45^{\mathrm{a}}$ & $15.03^{a}$ & $15.95^{\mathrm{a}}$ & 0.45 & 0.036 * \\
\hline FCR & 8,44 & 7.41 & 7.27 & 7.12 & 0.22 & $0.080^{n s}$ \\
\hline
\end{tabular}

\section{DISCUSSION}

\section{Blood parameter and immune organ}

The decreased heterophile and $\mathrm{H} / \mathrm{L}$ ratio in T3 (Table 2) gave an indication that the vitamin $\mathrm{C}$ of lime juice functions effectively and the chickens could cope with stress, due to the changes environmental, temperature, from in situ to ex situ conditions. The changes in environmental condition are greatly possible for the chickens suffer from the complexity of stressor. Vitamin C, or called as the chemical ascorbic acid, is a 6-carbon lactone that can be synthesized from glucose by poultry and some other animal species. Even though chicken can synthesis ascorbic acid (vitamin C), it is not enough to be able to overcome heat stress which is reported by Ahmadu et al. (2016). Therefore, chicken absolutely needs additional vitamin $\mathrm{C}$ from exogenous sources which in this study derived from lime juice. The $\mathrm{H} / \mathrm{L}$ ratio in present study was consistent with the report by Kusnadi et al. (2005) that dietary addition of vitamin $\mathrm{C}$ at $500 \mathrm{ppm}$ produced lower $\mathrm{H} / \mathrm{L}$ ratio with the average 0.61 than control (0.93). The decreased $H / L$ ratio was supported by lower heterophile even though lymphocytes did not change much (Table 2). This condition means that more vitamin $\mathrm{C}$ supplementation (from lime juice) increases body resistance. The increased some blood parameters impacted to the chicken's life more comfortable because it connected with the function of vitamin $\mathrm{C}$ that could reduce heat production due to low body protein catabolism (Kusnadi, 2006).

In contrast, endogenous vitamin C synthesis in the group of chickens given diet without lime juice supplementation (TO) and also those fed diet with low vitamin C supplementation of lime juice (T1) were not able or not enough to cope 
with environmental influences. When environmental condition change, especially in the tropic region with open house rearing system, show that it is great possible the adaptation mechanisms is occurred in relation to the decrease in body resistance (Dantzer and Mormède, 1983). Vitamin C in the condition of T0 treatment is absolutely needed to be function as an antidote or stress control for chickens. In the tropical country, heat stress could suppress blood parameter when the intake of micronutrients as antioxidants, especially vitamins C and E was low (Ahmadu et al., 2016) and negatively affect that greatly disrupted metabolic physiology, growth, and detrimental to the production performance in poultry (Attia et al., 2009; 2011; 2016).

The low effectiveness of vitamin $\mathrm{C}$ results in an increase in the $\mathrm{H} / \mathrm{L}$ ratio that occurs in TO and T1 treatments is in line with the increase in spleen weight (Table 2). The large size of the spleen indicates more and more antigens are accommodated so that free lymphocytes in the blood decreases because the spleen is tasked with taking antigens from the blood that have been bound to lymphocytes, ultimately increasing the $H / L$ ratio (Jamillah et al 2013). As discussed earlier, the $\mathrm{H} / \mathrm{L}$ ratio is an indicator of the comfort level of poultry life, in which the higher the ratio is, and then the $\mathrm{h}$ igher the discomfort is experienced by poultry (Kusnadi, 2009). Therefore, an unfavorable condition can cause an increase in the number of heterophiles and the total white blood cell according to Table 2.

The results (Table 2) indicated the phenomenon as evidence that vitamin $C$ is indeed as an antioxidant that can reduce the negative effects of environmental temperature changes. Gursu et al. (2003) reported that vitamin C can reduce the negative effects of new environments through the work of antioxidant systems that important to over-come. Vitamin $\mathrm{C}$ has $\mathbf{2}$ hydroxyl groups which are easily oxidized, therefore they can easily release electrons and hydrogen to be donated to free radicals so that free radicals were not reactive or became stable (Kusnadi, 2006). Vitamin C is powerful antioxidant with 2 mechanisms activity namely conversion to L-dehydroascorbic acid and the formation of ascorbic radicals (Ajakaiye et al., 2011). First, conversion to L-dehydroascorbic acid is a back and forth reaction, and molecular interchange can form a redox system physiologically back to its original vitamin $\mathrm{C}$ activity. Second, through the formation of ascorbate radicals that can destroy free radicals that formed by oxygen, such as hydroxyl $\left(\mathrm{OH}^{*}\right)$, mono-oxygen $\left(\mathrm{O}^{*}\right)$, and superoxide $\left(02^{*}\right)$. The mechanism mentioned above is closely related to other advantages of vitamin $\mathrm{C}$ which is able to restore the tocopherol radicals to a stable alpha tocopherol (Tamzil, 2014). These mechanisms may be proved by the decrease in $\mathrm{H} / \mathrm{L}$ ratio and relative weight spleen supported by increase total plasma protein (Table 2).

\section{Growth performance}

The effectiveness of vitamin $C$ in overcoming stress and increasing the ability to adapt to the ex situ condition (Semarang) with higher ambient temperatures can also be seen from the increase in plasma protein which further affect the productivity (Table 3). Total blood plasma protein in the treatment in T2 (2\% lime juice) and T3 (3\% lime juice) was higher as compared to T0 (without lime juice) and T1 (1\% lime juice) (Table 2). The addition of lime juice 2-3\% can increase total plasma protein. Examples of the normal range of total plasma proteins in broilers was between 4.14-4.53 $\mathrm{g} / \mathrm{dL}$ (Fattah et al., 2008). The increase in total plasma protein can be associated with a decrease in uric acid which is an indicator of the effect of giving vitamin C, and could increase the efficiency of protein use (Kusnadi, 2006), and decrease blood uric acid in laying hens (Saki et al., 2010). The use of protein was related to the effectiveness of controlling stressed by vitamin $C$ which could further suppress the body's protein catabolism; thereby, reducing plasma protein 2.6 to 2.9 $\mathrm{mg} / \mathrm{dL}$ in blood broilers (Gursu et al., 2003), and decrease plasma uric acid from $6.25 \mathrm{mg} / \mathrm{dL}$ (control) become 3.50 $\mathrm{mg} / \mathrm{dL}$ (Saki et al., 2010). This phenomenon was supported by the data vitamin $\mathrm{C}$ as much as $250 \mathrm{mg} / \mathrm{kg} \mathrm{can}$ increase plasma protein. The result of this study indicated that blood with increased supplementation level of lime juice. Heat stress, as indicated that Attia et al. (2017), that were significant decreased protein total $(-14.1 \%)$, albumin (-29.2\%), glucosa $(-6.8 \%)$, and increased $\mathrm{H} / \mathrm{L}$ ratio (+17.7). Vitamin $\mathrm{C}$ supplementation is very helpful in reducing the negative effects of heat stress on metabolic parameters by increasing blood parameter and productivity in broiler.

Vitamin $C$ levels derived from lime juice did not directly affect the feed intake of however; vitamin $C$ had more beneficial impact on body resistance (Table 2). Antioxidant compounds in lime juice could increase daily body weight gain, especially in T2 and T3 treatments. Antioxidant functions of vitamin C exert of its effect as free radical breaker and enzyme cofactor. The present result was supported by Bikrisima et al. (2014) that vitamin C derived from guava juice has been known function antioxidant functions as a free radical breaker and enzyme cofactor. Similarly, PokuJnr et al. (2018) reported that an addition of vitamin $\mathrm{C}$ at $10-30 \mathrm{mg} / \mathrm{bird} /$ day could increase feed intake, body weight gain, and FCR in Guinea fowl.

\section{CONCLUSION}

Supplemented vitamin C is the level of 3\% lime juice (T3) was indicated blood stability, to increase growth performance (daily body weight gain) and feed conversion ratio. The use of $3 \%$ lime juice resulted in the best outcomes for male pelung chicken growth. Lime juice needs to be extracted to get the real vitamin $\mathrm{C}$.

\section{DECLARATIONS}

Corresponding Author

E-mail: lilikkrismiyanto@lecturer.undip.ac.id; ORCID: 0000-0001-5634-6965 
Authors' Contribution

All authors contributed in research and writing, equally.

Conflict of interests

The authors declare that they have no competing interests.

\section{REFERENCES}

Abidin Z and Khatoon A (2013). Heat stress in poultry and the beneficial effects of ascorbic acid (vitamin C) supplementation during periods of heat stress. World's Poultry Science Journal, 69(1): 135-152. Google Scholar I Dol: https://doi.org/10.1017/S0043933913000123

Ahmadu S, Mohammed AA, Buhari H, and Auwal A (2016). An overview of vitamin C as an antistress in poultry. Malaysian Journal of Veterinary Research, 7(2): 9-22. link: http://www.dvs.gov.my/dvs/resources/user_14/MJVR_V7N2/MJVR-V7N2-p9-22.pdf

Ajakaiye JJ, Pérez AB., and Mollineda AT(2011). Effects of high temperature on production in layer chickens supplemented with vitamins C and E. Revista MVZ Córdoba, 16(1): 2283-2291. link: http://www.scielo.org.co/pdf/mvz/v16n1/v16n1a03.pdf

Ali S (2020). Lemon juice antioxidant activity against oxidative stress. Baghdad Science Journal, 17(Suppl.1): 207-213. Baghdad Science Journal (uobaghdad.edu.iq) I DOI: https://doi.org/10.21123/bsj.2020.17.1(Suppl.).0207

Asmara IY, Garnida, Tanwiriah W, and Partasasmita R (2019). Qualitative morphological diversity of female Pelung Chickens in West Java, Indonesia. Biodiversitas Journal of Biological Diversity, 20(1): 126-133. Biodiversitas Journal of Biological Diversity (smujo.id) I DOI: https://doi.org/10.13057/biodiv/d200115

Attia Y A, El-Hamid AEEA, Abedalla AA, Berik MA, Al-Harthi MA, Kucuk O, Sahin K, and Abou-Shehema BM (2016). Laying performance, digestibility and plasma hormones in laying hens exposed to chronic heat stress as affected by betaine, vitamin $\mathrm{C}$, and/or vitamin $\mathrm{E}$ supplementation. Springer Plus, 5: 1-12. Google Scholar I DOI: https://doi.org/10.1186/s40064-016-3304-0

Attia YA, Al-Harthi MA, El-Shafey A Rehab Y A and Kim WK (2017). Enhancing tolerance of broiler chickens to heat stress by supplementation with vitamin E, vitamin C and/or probiotics. Annals of Animal Science, 17(4): 1155-1169. Google Scholar I https://doi.org/10.1515/aoas-2017-0012

Attia YA, Hassan RA, and Qota MA (2009). Recovery from adverse effects of heat stress on slow-growing chicks in the tropics 1: Effect of ascorbic acid and different levels of betaine. Tropical Animal Health and Production, 41(5): 807-818. D0I: Google Scholar I https://doi.org/10.1007/s11250-008-9256-9

Attia YA, Hassan RA, Tag EI-Din AE and Abou-Shehema BM (2011). Effect of ascorbic acid or increasing metabolizable energy level with or without supplementation of some essential amino acids on productive and physiological traits of slow-growing chicks exposed to chronic heat stress. Animal Physiology and Animal Nutrition, 95(6): 744-755. Google Scholar I DoI: https://doi.org/10.1111/j.14390396.2010.01104.x

Belhadj Slimen I, Najar T, Ghram A, Abdrrabba M (2016). Heat stress effects on livestock: molecular, cellular and metabolic aspects, a review. Journal of Animal Physiology and Animal Nutrition, 100(3): 401-412. Google Scholar I DoI: https://doi.org/10.1111/jpn.12379

Bolton W (1967). Poultry Nutrition. MAFF Bulletin, No.174. HMSO, London. Google Scholar

Dantzer R and Mormède $P$ (1983). Stress in farm animals: a need for reevaluation. Journal of Animal Science, 57(1): 6-18. Dol: https://doi.org/10.2527/jas1983.5716

Directorate General of Livestock and Animal Health 2020. Livestock and Animal Health Statistics. Directorate General of Livestock and Animal Health, Ministry of Agricultural, Jakarta. Article link : Badan Pusat Statistik (bps.go.id)

Elwan HAM, Dawood DH, Abd El-Aziz El-Shafei SM, Abd El-Mohsen Abd El-Rahman A, Abdel-Latif SA, Mohany M, Alqahtani F, Alqahtani S and Al-Rejaie SS (2019). The potential role of Citrus limon powder as a natural feed supplement to boost the productive performance, antioxidant status, and blood biochemistry of growing rabbits. Animals, 9(7): 426. Google Scholar I DOI: https://doi.org/10.3390/ani9070426

Fattah SA, El-Sanhoury MH, El-Mednay NM, and Abdel-Azeem F (2008). Thyroid activity, some blood constituents, organs morphology and performance of broiler chicks fed supplemental organic acids. International Journal Poultry Science, 7(1): 215-222. Google Scholar DOI: https://dx.doi.org/10.3923/ijps.2008.215.222

Ferreira IB., Matos JrJB, Sgavioli S, Vicentini TI, Morita VS, and Boleli IC (2015). Vitamin C prevents the effects of high rearing temperatures on the quality of broiler thigh meat. Poultry Science, 94(5): 841-851. Google Scholar I DOI: https://doi.org/10.3382/ps/pev058

Gomez KA and Gomez AA 1984. Statistical Procedure for Agricultural Research. $2^{\text {nd }}$ ed. John Wiley and Sons Inc., New York. https://www.wiley.com/en-us/Statistical+Procedures+for+Agricultural+Research\%2C+2nd+Edition-p-9780471870920

Gursu MF, Onderci M, Gulcu F, and Sahin K (2003). Effects of vitamin C and folic acid supplementation on serum paraoxonase activity and metabolites induced by heat stress in vivo. Nutrition Research, 24(2): 157-164. Google Scholar I Dol: https://doi.org/10.1016/j.nutres.2003.11.008

Hidayat C and Asmarasari SA (2015). Native chicken production in Indonesia: a review. Jurnal Peternakan Indonesia (Indonesian Journa of Animal Science), 17(1): 1-11. Google Scholar I DOI: https://doi.org/10.25077/jpi.17.1.1-11.2015

Imik H, Kaynar O, Ozkanlar S, Gumus R, Polat H and Ozkanlar Y (2013). Effects of vitamin C and $\alpha$-lipoid acid dietary supplementations on metabolic adaptation of broilers to heat stress. Revue de Médecine Vétérinaire, 164(2): 52-59. Google Scholar I https://www.revmedvet.com/2013/RMV164_52_59.pdf

Jamilah, Suthama N and Mahfudz LD 2013. Production performance and immune responses of broilers given single step down diet with inclution of citric acid as acidifier. Indonesian Journal of Animal and Veterinary Sciences, 18(4): 251-257. DOI: Google Scholar I https://dx.doi.org/10.14334/jitv.v18i4.331

Kusnadi E (2006). Supplementation of vitamin C as antiheat-stress agen of broilers. Indonesian Journal of Animal and Veterinary Sciences 11(4): 249-253. Google Scholar I https://doi.org/10.14334/jitv.v11i4.533

Kusnadi E (2009). The change of liver malonaldehyde (mda), relative weight of bursa fabricius and heterophyl lymphocite ratio (H/L) of heat-stressed broilers. Tropical Animal Science Journal, 32(2): 81-87. Google Scholar

Kusnadi E, WIdjajakusuma R, Sutardi T, Hardjosworo PS and Habibie A (2005). Effect of antanan (Centella asiatica) and vitamin C on the bursa of fabricius, liver malonaldehide and performance of heat-stressed broilers. Biotropia, 24(1): 46-53. DOI: Google Scholar https://doi.org/10.11598/btb.2005.0.24.177 
Lohakare JD, Chae BJ and Hahn TW (2004). Effect of feeding methods (water vs feed) of vitamin C on growth performance and carcass characteristics in broiler chickens. Asian-Australian Journal Animal Science, 17(8): 1112-1117. Google Scholar I https://www.koreascience.or.kr/article/JAK0200410103463146.page

Marimuthu S, Selvam R, Kaninathan A, D'Souza P (2020). Effect of dietary supplementation of phytogenic feed additive on performance traits, serum neopterin, and cutaneous basophil hypersensitivity response in heat-induced stress model of broiler chickens. Journal of Advanced Veterinary and Animal Research, 7(1): 141-147. Google Scholar I DOI: http://doi.org/10.5455/javar.2020.g403

PokuJnr PA, Kyere CG, Seidu H and Twumasi G (2018). Effect of vitamin C supplementation on keet mortality, growth performance and blood profile of indigenous Guenia fowl (Numida meleagris) in Ghana. Livestock Research for Rural Development, 30 : Article \#196. Google Scholar I link: http://www.Irrd.org/Irrd30/11/kyere30196.html

Righi F, Pitino R, Manuelian CL, Simoni M, Quarantelli A, De Marchi M, Tsiplakou E (2021). Plant Feed Additives as Natural Alternatives to the Use of Synthetic Antioxidant Vitamins on Poultry Performances, Health, and Oxidative Status: A Review of the Literature in the

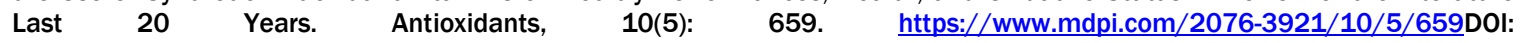
https://doi.org/10.3390/antiox10050659

Sahin K, Sahin N and Küçük $O$ (2003). Effects of chromium and ascorbic acid supplementation on growth, carcass traits, serum metabolities, and antioxidant status of broiler chickens reared at a high environmental temperature (32。 $\mathrm{C}$ ). Nutrition Research, 23(2): 225-238. Google Scholar I DOI: https://doi.org/10.1016/S0271-5317(02)00513-4

Saki AA, Rahmati MMH, Zamani P, Zaboli K, and Matin HRH (2010). Can vitamin C elevate laying hen performance,egg and plasma characteristics under normal environmental temperature. Italian Journal Animal Science, 9(3): 312-317. Google Scholar I https://www.tandfonline.com/doi/full/10.4081/ijas.2010.e60

Shrestha RL, Dhakal DD, Gautum DM, Paudyal KP and Shrestha S (2012). Variation of physiochemical components of acid lime (citrus aurantifolia swingle) fruits at different sides of the tree in Nepal. American Journal of Plant Sciences, 3(12): 1688-1692. Google Scholar I http://dx.doi.org/10.4236/ajps.2012.312206

Sumantri C, Khaerunnisa I, and Gunawan A (2020). The genetic quality improvement of native and local chickens to increase production and meat quality in order to build the Indonesian chicken industry. IOP Conference Series: Earth and Environmental Science, 492(1): 012099. Link: https://iopscience.iop.org/article/10.1088/1755-1315/492/1/012099/meta

Surai PF, Kochish II, Fisinin VI, Kidd MT (2019). Antioxidant Defence Systems and Oxidative Stress in Poultry Biology: An Update. Antioxidants (Basel): 8(7): 235. Google Scholar I DOI: https://dx.doi.org/10.3390\%2Fantiox8070235

Tamzil MH (2014). Heat stress on poultry: metabolism, effects and efforts to overcome. Wartazoa, 24(2): 57-66. Google Scholar https://medpub.litbang.pertanian.go.id/index.php/wartazoa/article/view/1049

Zhou Y, Mao S, and Zhou M (2019). Effect of the flavonoid baicalein as a feed additive on the growth performance, immunity, and antioxidant capacity of broiler chickens. Poultry Science, 98(7): 2790-2799. Google Scholar I DOI: https://doi.org/10.3382/ps/pez071 